Article

\title{
Contrasting Effects of Fire Severity on the Regeneration of Pinus halepensis Mill. and Resprouter Species in Recently Thinned Thickets
}

\author{
Ruth García-Jiménez, Marina Palmero-Iniesta and Josep Maria Espelta * \\ CREAF, Cerdanyola del Vallès, Catalonia 08193, Spain; Ruth.garciajimenez@gmail.com (R.G.-J.); \\ marpa86@hotmail.com (M.P.-I.) \\ * Correspondence: Josep.Espelta@uab.cat; Tel.: +34-9358-1467-1 \\ Academic Editors: Xavier Úbeda and Victoria Arcenegui \\ Received: 23 December 2016; Accepted: 21 February 2017; Published: 24 February 2017
}

\begin{abstract}
Many studies have outlined the benefits for growth and reproduction resulting from thinning extremely crowded young forests regenerating after stand replacing wildfires ("thickets"). However, scarce information is available on how thinning may influence fire severity and vegetation regeneration in case a new fire occurs. We investigated the relationship between thinning and fire severity in P. halepensis thickets, and the effects on the establishment of pine seedlings and resprouting vigour in resprouter species the year after the fire. Our results show a positive relationship between forest basal area and fire severity, and thus reserved pines in thinned stands suffered less fire damage than those in un-thinned sites (respectively, $2.02 \pm 0.13$ vs. $2.93 \pm 0.15$ in a scale from 0 to 4 ). Ultimately, differences in fire severity influenced post-fire regeneration. Resprouting vigour varied depending on the species and the size of individuals but it was consistently higher in thinned stands. Concerning P. halepensis, the proportion of cones surviving the fire decreased with fire severity. However, this could not compensate the much lower pine density in thinned stands and thus the overall seed crop was higher in un-thinned areas. Establishment of pine seedlings was negatively affected by the slope and positively driven by the number of cones and thus it was higher in un-thinned than in thinned stands (respectively, $2581 \pm 649$ vs. $898 \pm 325$ seedlings.ha ${ }^{-1}$ ). Thinning decreases fire intensity, and thus it may facilitate fire suppression tasks, but retaining a higher density of pines would be necessary to ensure P. halepensis regeneration after a new fire event.
\end{abstract}

Keywords: fire severity; Mediterranean forests; Pinus halepensis; post-fire regeneration; seed bank; selective thinning

\section{Introduction}

Germination of seeds protected in a soil or canopy seed bank is one of the main regeneration mechanisms developed by plants to cope with fire, the most frequent disturbance in Mediterranean type ecosystems [1-3]. This post-fire regeneration strategy often results in the direct recovery of the same plant community ("autosuccession" sensu [4], but see [5]), contributes to avoid soil erosion [6] and promotes the fast return of crucial ecosystem services [7,8]. Notwithstanding these benefits, the too profuse establishment of tree seedlings ("thickets" or "dog hair stands") entails some constrains concerning forest development, as competition precludes tree growth and reproduction $[9,10]$ while increases the risk of new stand-replacing wildfires before a new seed bank has developed ("immaturity risk" $\left.^{\prime \prime},[11,12]\right)$.

Density control (i.e., thinning) in young thickets is strongly recommended to reduce between-tree competition, thus enhancing tree growth and reproduction and improving forest structure and dynamics $[9,10,13-15]$. Previous studies have shown that reducing tree density in highly crowded 
thickets usually promotes an early reproduction onset, a higher number of reproductive trees, a higher seed crop size per tree [9,13,14,16,17], and an overall increase in forest biodiversity [18]. In addition, simulations of fire behaviour in thickets have shown that thinning has an important effect in reducing fire intensity and spread, for example, a reduction in flame length from $9.7 \pm 0.2$ to $1.6 \pm 0.3$ in pine thickets $[19,20]$. In comparison to the numerous studies that have stressed the benefits of early thinning for forest structure and stand development, little attention has been paid to the effects that a new fire event might produce in early thinned stands and how they might recover after this disturbance. Some studies have pointed out a decrease in fire severity in managed stands, but most of them refer to mature forests [21,22]. Moreover, in young thickets, owing to the lack of commercial value, removed saplings are usually chopped and laid on the ground as dead down material [23], an effect that has been barely considered in studies analyzing the effects of thinning on fire severity.

Pinus halepensis Mill. (Aleppo pine) is one of the obligate-seeding tree species most widespread in the Mediterranean Basin directly or indirectly favored by human activities and now covers about 2.5 million ha mainly on the western rim [3]. After a fire event, the massive liberation of seeds, partly protected in serotinous cones, often allows a successful regeneration of Aleppo pine forests, resulting in high density and almost monospecific stands dominated by this species $[9,10,16,24]$. In these thickets, density reduction is often conducted to promote tree growth and reproduction onset $[9,13,14,16,17]$, thus reducing the immaturity risk period [25], in light of increasing disturbances (e.g., fire, drought) in the region owing to climate change [7]. The main aim of this study was to investigate the regeneration success after the occurrence of a new fire event in recently thinned vs. un-thinned P. halepensis thickets (ca. 30 years old) regenerating after a previous stand replacing wildfire. As fire severity has been established as an important parameter for predicting the magnitude of vegetation structural and compositional changes after fire [26-28], we have focused on the effects of thinning on this trait, and the effects of fire severity on post-fire regeneration. The two specific objectives of the present work were: (1) to investigate if there is a relationship between thinning intensity and fire severity and (2) to assess whether this influences the regeneration success of $P$. halepensis and the vigour of resprouting of the main resprouter species present in the area.

\section{Material and Methods}

\subsection{Study Area and Species}

This study was carried out in El Bruc in the province of Barcelona, in an area frequently affected by wildfires ( $41^{\circ} 34^{\prime} \mathrm{N}, 1^{\circ} 46^{\prime} \mathrm{E}$, Catalonia, NE Spain) (Figure 1). The average altitude is $478 \mathrm{~m}$ (ranging from $232 \mathrm{~m}$ to $551 \mathrm{~m}$ ) and climate is dry-subhumid continental Mediterranean (according to the Thornwaite index), with mean annual temperature of $14-16^{\circ} \mathrm{C}$ and mean annual precipitation of 550-650 mm [29]. The soil is composed of Paleozoic materials, mainly by easily eroded quartz shale [30]. The study area is mainly covered by ca. 30-year-old P. halepensis thickets that regenerated after a large wildfire episode in 1986. Pinus halepensis is an "obligate seeder species" typical from the western rim of the Mediterranean Basin which is commonly able to withstand intense and stand-replacing wildfires owing to its high regeneration ability [31]. This successful post-fire recovery is based upon a short juvenile period, early flowering, the production of large cone crops and a weak serotinous habit [3]. In the pine forests of the study area, there were also some common resprouter species such as Erica multiflora L., Quercus coccifera L., Pistacia lentiscus L. and Viburnum tinus L. mostly found in the understory layer. 


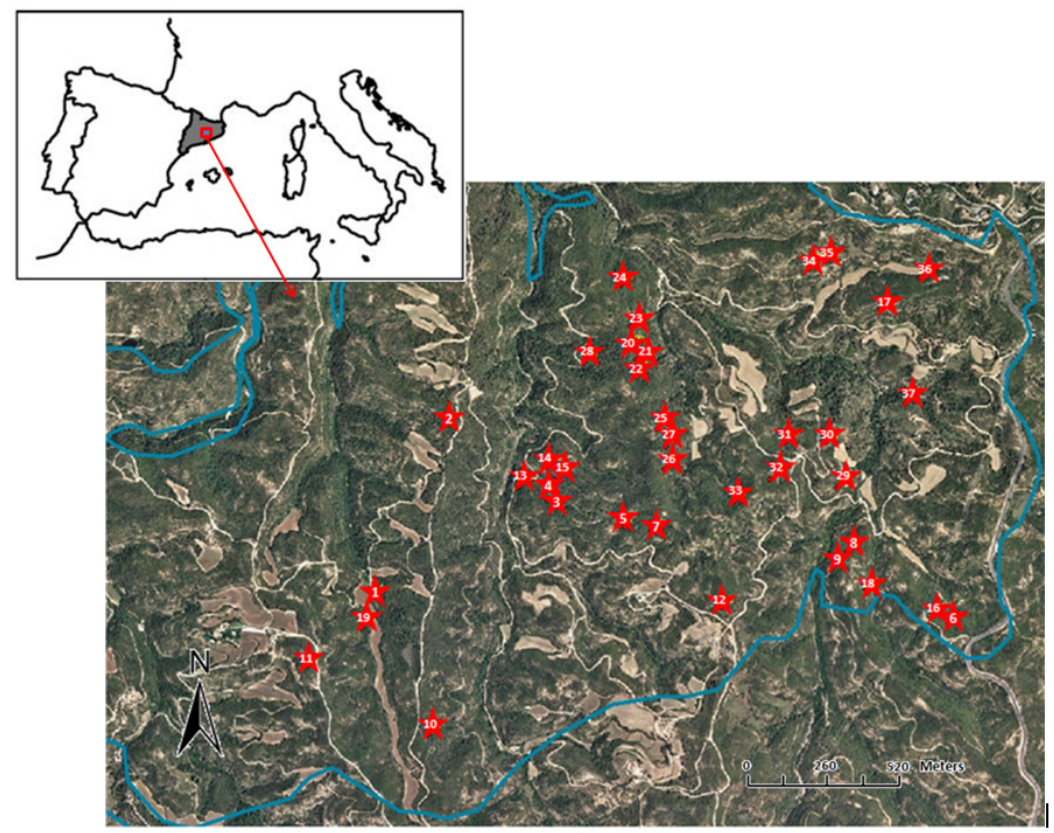

Figure 1. Location of the study site and the 37 plots sampled in the area affected by the 2015 wildfire (delimited in blue) in El Bruc (Catalonia, NE Spain). See Table A1 to assign each plot to the un-thinning or thinning treatment.

In the spring of 2015, a manual thinning was conducted by the local association of landowners (Entorns de Montserrat) to promote tree growth and reproduction while reducing the risk of spread of new wildfires [9,32], see a general view of the thinned forest in Figure 2A. Removed saplings were chopped and laid on the soil and they started to dry quickly, with a $6.5 \% \pm 4.1 \%$ water content by the end of June (JM Espelta, unpublished results). In July 2015, a wildfire that originated in a surrounding P. halepensis forest burned 565 ha of mature forest, 217 ha of un-thinned and 300 ha of thinned thickets, where the fire was finally suppressed (Figure 2B).

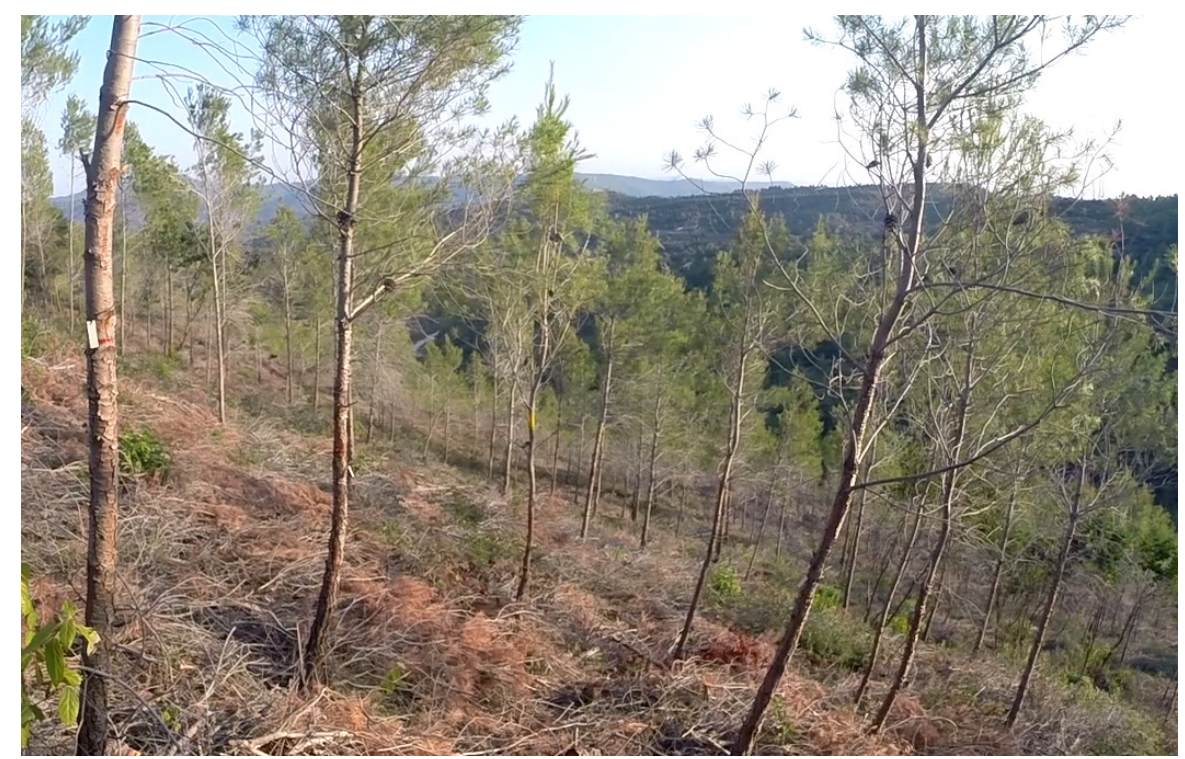

(A)

Figure 2. Cont. 


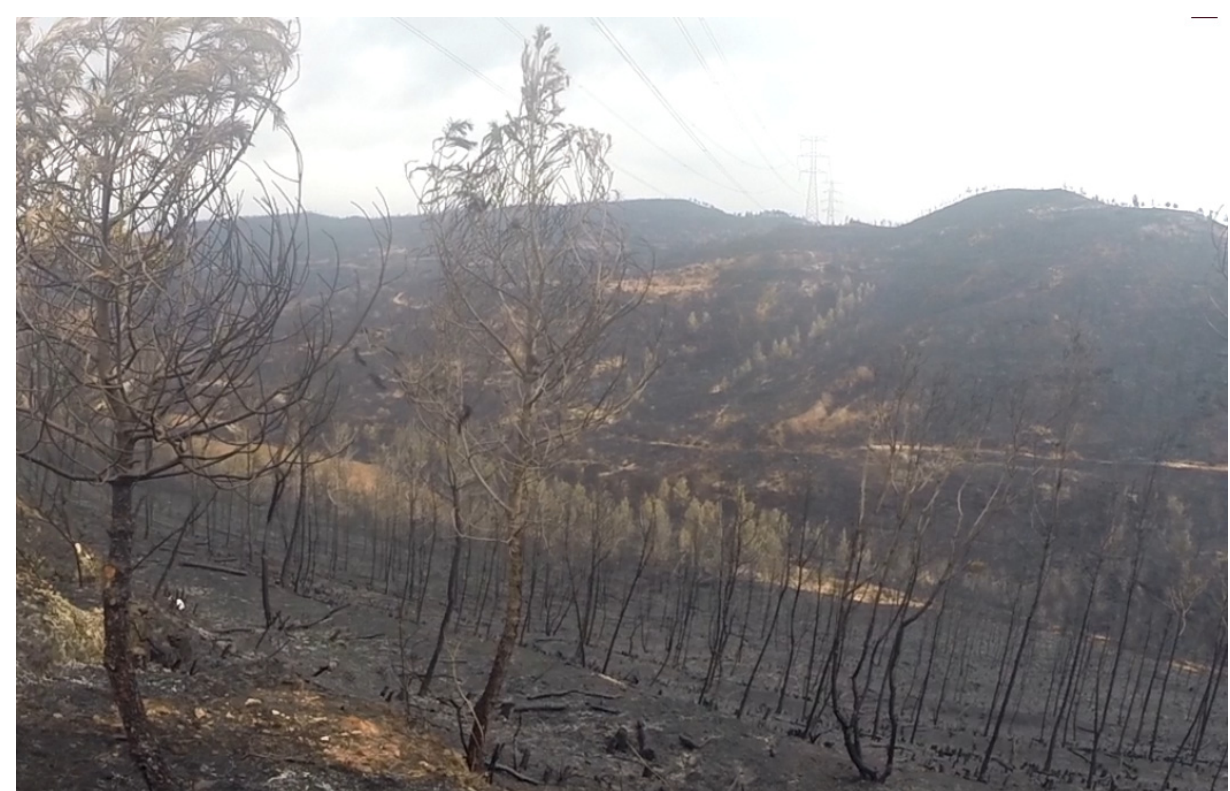

(B)

Figure 2. General view of a thinned P. halepensis thicket prior (A) and after (B) the 2015 wildfire. Notice that during thinning, removed trees were chopped and laid down on the ground.

\subsection{Experimental Design and Sampling}

To determine the effects of topography and forest structure on fire severity and the regeneration success of these young P. halepensis forests after a second wildfire in a relatively short time lapse (1986, 2015), we randomly established 37 circular plots (10 m radius) in early 2016 in both un-thinned and thinned sites across the study area (respectively, 15 and 22 plots). Each plot was geolocated by means of a GPS and we determined elevation, aspect and slope. Then, we carried out a forest inventory of the tree layer (almost monospecific stands of $P$. halepensis) by measuring tree diameter at breast height (DBH) and height. We also annotated the presence of all species resprouting after the fire and their abundance.

In each plot, we classified all trees according to a fire damage degree as a proxy of fire severity. We used an index including five increasing categories of damage caused by fire [33,34]: (i) live trees (score 0); (ii) dead trees with crowns that were scorched but not consumed by fire (score 1); (iii) trees with no needles that still maintain secondary branches with a diameter smaller than $0.7 \mathrm{~cm}$ (Score 2); (iv) trees that maintain branches with a diameter larger than $0.7 \mathrm{~cm}$ but smaller than $2.5 \mathrm{~cm}$ (Score 3) and v) trees bearing only branches with a diameter larger than $2.5 \mathrm{~cm}$ or just remnants of the main trunk (Score 4) (see Figure 3). All the trees sampled in the plots were dead, and thus we did not find live trees with a 0 score of fire damage. In order to collect supplementary information on possible differences in fire severity between thinned and un-thinned plots, we also estimated, by means of two perpendicular transects, the number and volume of woody residues-left when the thinning treatment was applied - that still remained after the fire. The main topographic and structural characteristics of the sampled plots are shown in Table A1. 


\section{Categories of fire severity}

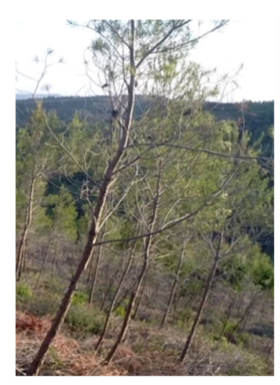

Level 0

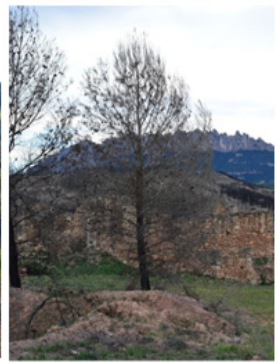

Level 1

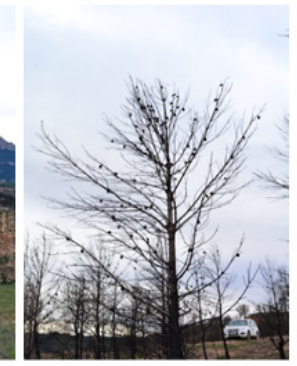

Level 2

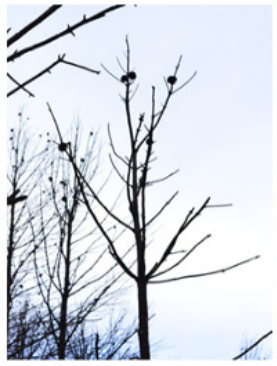

Level 3

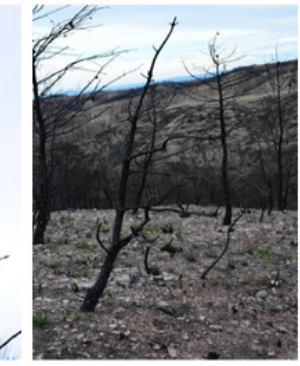

Level 4

Figure 3. Fire severity index with five levels of fire severity: (0) trees alive; (1) trees which still maintain brown needles; (2) trees which maintain secondary branches, often with a diameter smaller than $0.7 \mathrm{~cm}$; (3) trees which only maintain primary branches, often with a diameter larger than $0.7 \mathrm{~cm}$ but smaller than $2.5 \mathrm{~cm}$; (4) trees which maintain only the main trunk.

To determine the canopy seed bank of pines, we counted for each pine the number of cones, distinguishing between those that resisted the fire (hereafter, sound cones) from those that were destroyed (hereafter, charred), and we computed the proportion of sound cones per pine over the total cone crop. From these values, we calculated the proportion of sound cones per plot (see, for a similar procedure [9]). Furthermore, to assess if fire might have depressed seed viability in sound cones, we randomly selected just after the fire, 7 sound cones of 5 different pines in 6 of the sampled plots for analyses. Once in the laboratory, we calculated the percentage of fully developed seeds after cutting 30 pinions per individual tree and selected 15 seeds per tree to determine the germination percentage in Petri dishes [35]. We did not conduct a similar experiment with seeds from charred cones because they were mostly ashes. To assess the real regeneration success of $P$. halepensis one year after the fire event, in 2016 we came back to the 37 plots established in the field and counted the number of seedlings present. During that visit, we also characterized the resprouting vigour of the different resprouting species present in the plots by measuring the height of the tallest sprout and crown area [36]. We calculated the biovolume for each individual by multiplying the mean height of resprouts and crown area. We also recorded the number of stumps and their basal diameter, as a proxy of the size of the individual before the fire event [37]. See Table A2 for a list of the main resprouter species present in the study area.

\subsection{Data Analysis}

First, we checked for the correlation degree among all variables and excluded those with a significant correlation coefficient higher than 0.6 from the subsequent statistical analysis to avoid spurious relationships. To test for the effects of topographic characteristics (aspect, slope, elevation and geographic location), characteristics of the tree layer (basal area and height) and the number and minimum diameter of burned slash (proxy of the surface fuel available before the fire) on the fire severity degree observed in the tree layer, we applied stepwise multiple linear regression analyses. The effect of the fire severity index on the proportion of sound cones per pine, seed viability (number of full seeds per cone) and germination ability was analysed by means of general linear mixed models (GLMM) including plot as a random factor. Concerning the success of $P$. halepensis regeneration after fire, we assessed by means of a Generalized Linear Model (GLZ), the effect on seedling density of the seed crop size (i.e., estimated number of sound cones per plot) and topographic constraints (slope of the plot), as these are two of the most critical factors reported to drive the post fire regeneration success of this species $[24,25,27]$. For resprouter species, the effects of fire severity on the resprouting vigour 
(maximum sprout height, crown cover and biovolume) was analysed by means of three different GLMMs including plot as a random factor. In these analyses, we also included the species and the number and surface of stumps per individual to account for species-specific differences and the influence of the previous size of individuals before the fire [37,38]. In all cases, inspection of residuals was carried out to check for normality and homoscedasticity. When necessary, we ran analyses on transformed data. We performed all these statistical analyses using SPSS version 20.0 (IBM, Armonk, NY, USA) or the R statistical software [39]) with the lme4 [40] and MuMIn [41] packages. In the text, mean values are accompanied by the standard error (Mean \pm 1SE).

\section{Results}

The fire severity index, based on the presence of needles and the size of tree branch remnants, indicated an intermediate fire severity across the study area (2.35 \pm 0.12 on a scale from 0 to 4$)$. However, fire severity significantly increased with basal area in the plots $(F=12.15, p \leq 0.001$, $R^{2}=0.26$; Figure 4) and therefore it was higher in un-thinned than in thinned stands (respectively, $2.93 \pm 0.15$ vs. $2.02 \pm 0.13 ; F=19.41, p=0.003$ ). Fire severity influenced significantly and negatively the proportion of sound cones per pine $\left(F=28.4, p \leq 0.001, R^{2}=0.63\right)$ and thus this proportion was higher in areas with less basal area: i.e., $0.90 \pm 0.02$ in thinned vs. $0.79 \pm 0.03$ in un-thinned plots, $F=9.81, p=0.014$. However, the higher sound cone bank per pine in thinned stands could not compensate for the much lower number of trees present and thus the estimated overall crop size of sound cones was ca. three times higher in un-thinned sites, in spite that they suffered higher fire severity (i.e., $27,314 \pm 3988$ cones ha $^{-1}$ in un-thinned vs. 10,028 \pm 3293 cones $^{-h^{-1}}{ }^{-1}$ in thinned plots). Neither the number of full seeds in sound cones nor their germination ability were affected by fire severity $(p>0.05)$. One year after the fire event, the presence of seedlings of P. halepensis was observed in $78 \%$ of the plots, although density was extremely variable $\left(1580 \pm 431\right.$ seedlings.ha ${ }^{-1}$; min. $=0$ seedlings $\cdot$ ha $^{-1}$, max. $=10,315$ seedlings $\cdot$ ha $\left.^{-1}\right)$. The presence of $P$. halepensis seedlings was negatively affected by the slope and positively driven by the amount of sound cones per stand after the fire event (respectively, $F=11.5, p=0.0244$ and $F=16.9, p=0.0013$ ). This effect of the size of the sound cone crop resulted in the density of Aleppo pine seedlings being higher in un-thinned than in

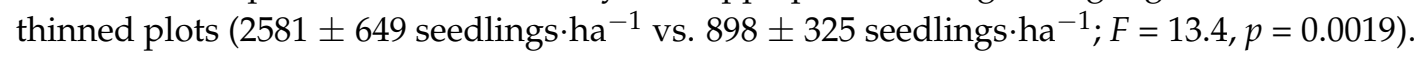

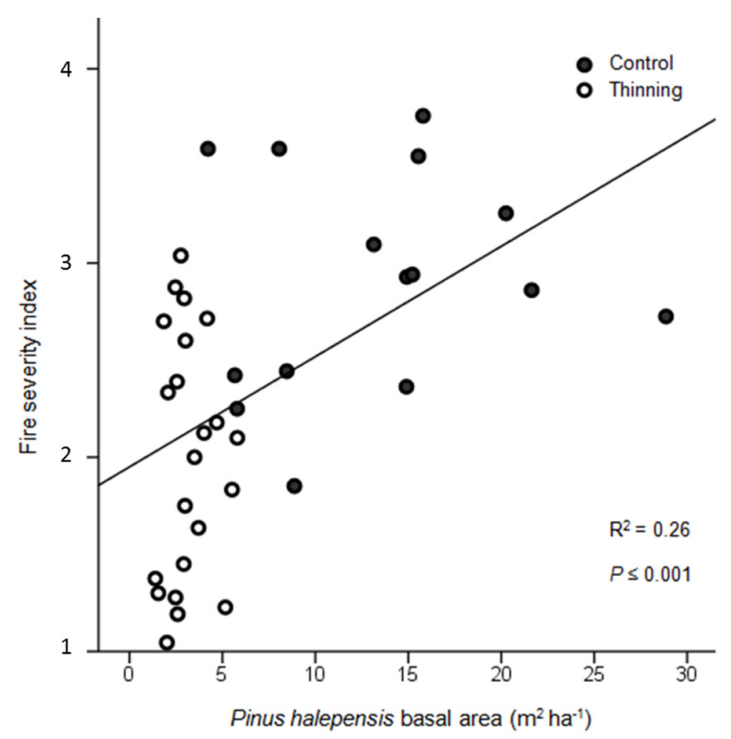

Figure 4. Relationship between Pinus halepensis basal area and the fire severity index. The two different management treatments are indicated: control (solid circles) and thinning (open circles). $n=37$ plots. 
Resprouting vigor (height, cover and biovolume) in resprouter species was significantly influenced by the size of the individuals before the fire event (Table 1), although the strength of this relationship varied among the different species (interaction species $x$ surface of stumps in Table 1, Table A2 and Figure A1). Fire severity showed a significant and negative influence on the three proxies of resprouting vigor (height, cover and biovolume) (Table 1). Therefore, as fire severity was higher in the un-thinned plots, resprouting vigor was higher in the thinned ones.

Table 1. Results of the general linear mixed models to test the effects of fire severity (Sev), species (Sp), stump number (Sn) and stump surface (Ss) and plot (random factor) on three proxies of resprouting vigor (total height, total cover and biovolume). Stump n. = stump number, Stump s. = Stump surface. Significant effects $(p<0.05)$ are indicated in bold.

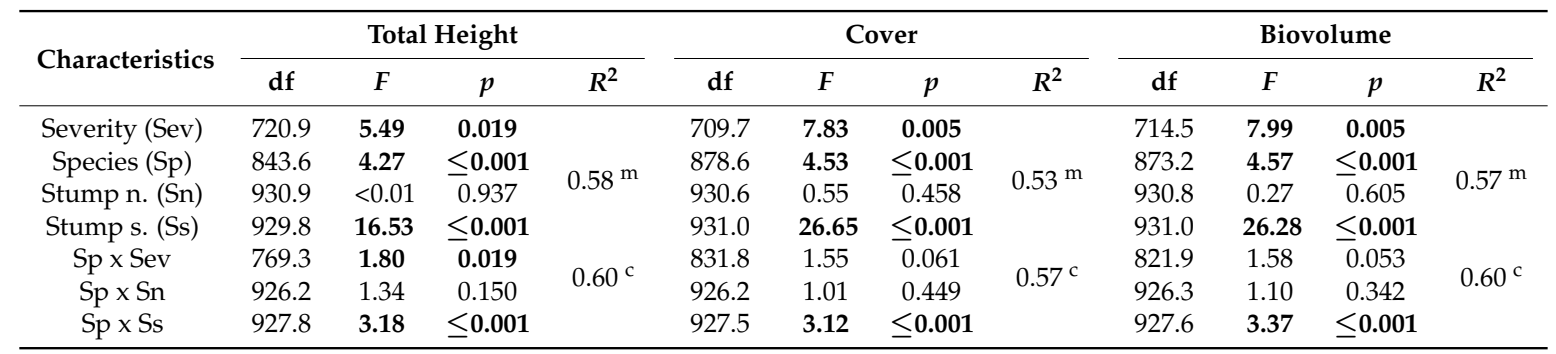

$\mathrm{df}=$ degrees of freedom, $\mathrm{m}=$ marginal $R^{2}$, proportion of variance explained by the fixed factors alone, $\mathrm{c}=$ conditional $R^{2}$, proportion of variance explained by both the fixed and random factors.

\section{Discussion}

The main contribution of this study is to show that there is a relationship between thinning and fire severity, and ultimately, post-fire vegetation recovery. Our results indicate that the areas that were thinned before the fire event presented less fire damage (i.e., less fire severity) than un-thinned stands, where P. halepensis basal area was higher. The lower fire severity observed in the thinned plots is probably related to the reduction of crown overlapping and ladder fuel (contiguous vertical fuels) after thinning $[20,23,42,43]$. In fact, in a companion study conducted in the same study area, it was observed that thinning reduced fire spread rate, fire intensity at the frontline, and especially flame length from $9.5 \pm 0.2 \mathrm{~m}$ to $1.6 \pm 0.3 \mathrm{~m}$ compared to the un-thinned areas [19]. Interestingly, these results match with the fact that we observed many pines still bearing brown needles in the thinned areas (Level 1 of Severity) but almost none in the un-thinned stands.

The difference in $P$. halepensis basal area among plots had a stronger effect on fire severity than tree height or topographic conditions, two factors traditionally assumed to largely influence fire behaviour $[26,28,44]$. Even though several studies indicate that tree height is the main factor driving fire severity because larger trees are more fire-resistant due to their taller crowns and thicker bark [22,26], tree size did not have any effect in our study, probably owing to the similar height of pines both in un-thinned and recently thinned plots (respectively, $5.2 \mathrm{~m} \pm 1.2 \mathrm{~m}$ vs. $5.3 \mathrm{~m} \pm 1.4 \mathrm{~m}$; Table A1). Concerning the presence of remnant slash in the thinned stands, several studies have suggested that it may increase fuel availability, raising the probability of more intense and extensive wildfires in the future [44,45], although these studies refer to mature forest and most of them have not experimentally tested or observed these potential effects. Interestingly, our results indicate that surface fuel (slash) in thinned plots did not increase fire severity, at least at the tree level (see [19]). Moreover, this effect was obtained in spite of the short interval between thinning and wildfire (ca. two months) when fine fuels were still very abundant (see Figure 2A). Simulations of fire behavior, considering the rate of slash decay measured nearby, suggests that in 2-3 years, fire behavior parameters will be even lower in the thinned thickets in comparison to the un-thinned ones [19].

As shown by our results, the probability of maintaining sound (non-charred) cones per pine decreased with fire severity [46], and thus it was higher in thinned stands. However, the total crop of sound cones was considerably larger in un-thinned plots where the number of pines was much higher 
(see [9]). The observed post-fire recruitment of $P$. halepensis seedlings showed an extremely variable density, as reported in similar studies $[24,27,47,48]$ but it was significantly higher in un-thinned plots and in stands with smoother slopes. Moreover, as observed in other studies, regeneration success of $P$. halepensis is often better on flat areas or with a moderate slope where seeds tend to accumulate and water retention capacity is higher $[24,27,48]$. In light of the mean density of seedlings recruited one year after the fire in the thinned thickets (ca. 900 seedlings.ha ${ }^{-1}$ ) and considering the probable mortality events specially during the first years [3], we suggest reserving a density of pines higher than the current ca. 1000 trees $\cdot \mathrm{ha}^{-1}$ during the thinning operations and a mosaic of thinned and un-thinned areas, with the aim of assuring enough seed availability and seedling recruitment in case a new fire occurs [9]. Of course, this recommendation should also be confronted with the higher fire intensity and severity observed in the stands with larger basal area (this study, [19]), stressing the need to adapt the management of these thickets to the landscape characteristics both to ensure their resilience but also the reduction of fire spread. Moreover, regeneration will depend not only on the previous density of pines but also on the weather conditions just after fire and on post-fire management decisions (e.g., salvage logging, drag of trunks), which may enhance or reduce the recruitment values found $[49,50]$.

Conversely to the results found for the regeneration success of the seeder P. halepensis, resprouting vigour was higher in thinned plots where fire severity was lower, probably because intense fire causes the physical destruction of part of the bud-bank, damages superficial roots and it negatively affects the physiology of the stumps in species with this post-fire regeneration strategy [36,51-53]. However, the effects were somewhat species-specific (Table 1): i.e., one of the species more affected by fire was J. oxycedrus [27,38], while P. angustifolia and A. unedo were among the ones with a better response $[37,54,55]$. Moreover, resprouting vigour varied according to the individual size before the wildfire event (Figure A1, [37]) and thus, individuals that were bigger in terms of stumps surface, produced more vigorous resprouts (taller and leafier) after the fire. This positive effect has been argued to rely on a larger size of the number of buds [56] and on larger under-ground reserves [57].

\section{Conclusions}

Present day evidences suggest that repeated fires in a short interval may delay the reproduction onset in Aleppo pine forests [58] while the recurrence of drought events reduce their canopy seed bank [59]. On the basis of a future rise of wildfire recurrence and water stress as a result of land use and climate changes, there is an urgent need to develop management strategies for increasing Mediterranean-type forests resilience [1]. According to our results, we can conclude that thinning may decrease fire severity in young pine thickets and has contrasting effects on the post-fire regeneration success of plants depending on their post-fire strategy (seeder or resprouter). Interestingly, we also proved that the presence of slash remnants in the thinned plots ddoes not increase fire severity and fire damage is only controlled by the amount of standing basal area. Thinning appears as a promising silvicultural tool to ameliorate the structure and development of these young P. halepensis thickets and to create more fire resilient stands [60]. However, the final density of retained saplings in a particular stand as well as the spatial arrangement of un-thinned and thinned thickets at the landscape level should be adapted to match and balance three simultaneous objectives: i.e., increase growth and reproduction of pines, reduce fire intensity and damage, and ensure the resilience of the forest to new wildfire events.

Acknowledgments: Thanks are due to Guillem Bagaria for field assistance. This study has been partly funded by the Oficina Tècnica de Prevenció Municipal d'Incendis Forestals (OTPMIF, Diputació de Barcelona), the project BEEMed (SGR913 Generalitat de Catalunya) and it benefited from the thinning treatments carried out in the LIFE Montserrat Project (LIFE13 BIO/ES/000094).

Author Contributions: Josep Maria Espelta, Ruth García-Jiménez and Marina Palmero-Iniesta conceived the study. Ruth García-Jiménez and Marina Palmero-Iniesta carried out the field work. Ruth García-Jiménez and Josep Maria Espelta analyzed the data and wrote the manuscript.

Conflicts of Interest: The authors declare no conflicts of interest. 


\section{Appendix A}

Table A1. Main topographic and structural characteristics of the plots. Height is expressed as mean \pm S.E. Density of P. halepensis seedlings established after the fire is indicated.

\begin{tabular}{|c|c|c|c|c|c|c|c|c|}
\hline Plot & Treatment & $\begin{array}{l}\text { Elevation } \\
\text { (m) }\end{array}$ & $\begin{array}{l}\text { Aspect } \\
\left({ }^{\circ}\right)\end{array}$ & $\begin{array}{l}\text { Slope } \\
\left({ }^{\circ}\right)\end{array}$ & $\begin{array}{c}\text { Density } \\
\left(\text { pines }^{\prime} \mathrm{ha}^{-1} \text { ) }\right.\end{array}$ & $\begin{array}{l}\text { Basal Area } \\
\left(m^{2} \cdot h^{-1}\right)\end{array}$ & $\begin{array}{l}\text { Height } \\
\text { (m) }\end{array}$ & 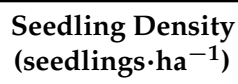 \\
\hline 1 & Control & 485 & 280 & 19 & 8315 & 5.67 & $3.5 \pm 0.2$ & 260 \\
\hline 2 & Control & 504 & 305 & 14 & 1754 & 8.87 & $5.5 \pm 0.1$ & 3118 \\
\hline 3 & Control & 480 & 30 & 26 & 2209 & 8.05 & $5.6 \pm 0.0$ & 10,134 \\
\hline 4 & Control & 469 & 10 & 20 & 5587 & 21.63 & $8.5 \pm 0.1$ & 7535 \\
\hline 5 & Control & 503 & 225 & 14 & 10,654 & 20.25 & $6.7 \pm 0.1$ & 1559 \\
\hline 6 & Control & 513 & 20 & 28 & 13,252 & 14.90 & $4.7 \pm 0.0$ & 2079 \\
\hline 7 & Control & 501 & 215 & 22 & 16,630 & 15.79 & $4.5 \pm 0.1$ & 1039 \\
\hline 8 & Control & 480 & 300 & 15 & 15,591 & 28.86 & $5.9 \pm 0.1$ & 6496 \\
\hline 9 & Control & 479 & 310 & 16 & 18189 & 15.54 & $5.0 \pm 0.0$ & 2598 \\
\hline 10 & Control & 523 & 90 & 19 & 1299 & 5.79 & $4.1 \pm 0.0$ & 1039 \\
\hline 11 & Control & 551 & 15 & 18 & 7276 & 14.92 & $4.2 \pm 0.0$ & 0 \\
\hline 12 & Control & 506 & 230 & 25 & 6236 & 8.46 & $4.0 \pm 0.1$ & 260 \\
\hline 13 & Control & 466 & 290 & 23 & 5457 & 13.14 & $5.0 \pm 0.0$ & 1299 \\
\hline 14 & Control & 461 & 230 & 18 & 3313 & 4.22 & $5.0 \pm 0.0$ & 780 \\
\hline 15 & Control & 463 & 255 & 26 & 5457 & 15.21 & $5.7 \pm 0.1$ & 520 \\
\hline 16 & Thinned & 444 & 15 & 29 & 715 & 2.94 & $3.7 \pm 0.1$ & 1819 \\
\hline 17 & Thinned & 482 & 184 & 23 & 585 & 2.55 & $4.9 \pm 0.1$ & 0 \\
\hline 18 & Thinned & 487 & 50 & 27 & 1039 & 1.39 & $3.3 \pm 0.1$ & 780 \\
\hline 19 & Thinned & 232 & 90 & 26 & 780 & 4.01 & $5.1 \pm 0.1$ & 1039 \\
\hline 20 & Thinned & 482 & 55 & 27 & 585 & 2.48 & $5.7 \pm 0.1$ & 6236 \\
\hline 21 & Thinned & 473 & 105 & 24 & 650 & 1.55 & $3.7 \pm 0.1$ & 0 \\
\hline 22 & Thinned & 482 & 50 & 26 & 520 & 3.50 & $7.0 \pm 0.1$ & 260 \\
\hline 23 & Thinned & 482 & 60 & 27 & 715 & 5.16 & $7.0 \pm 0.1$ & 0 \\
\hline 24 & Thinned & 473 & 5 & 26 & 974 & 5.80 & $6.4 \pm 0.1$ & 1039 \\
\hline 25 & Thinned & 500 & 95 & 22 & 650 & 1.85 & $5.3 \pm 0.2$ & 0 \\
\hline 26 & Thinned & 505 & 80 & 28 & 520 & 2.99 & $5.7 \pm 0.1$ & 520 \\
\hline 27 & Thinned & 497 & 15 & 28 & 585 & 2.07 & $4.8 \pm 0.1$ & 260 \\
\hline 28 & Thinned & 483 & 240 & 30 & 715 & 3.71 & $4.2 \pm 0.1$ & 260 \\
\hline 29 & Thinned & 457 & 120 & 23 & 780 & 2.47 & $3.9 \pm 0.1$ & 260 \\
\hline 30 & Thinned & 453 & 80 & 16 & 909 & 4.69 & $6.0 \pm 0.1$ & 520 \\
\hline 31 & Thinned & 468 & 315 & 10 & 650 & 2.92 & $4.7 \pm 0.06$ & 0 \\
\hline 32 & Thinned & 503 & 75 & 14 & 844 & 2.76 & $3.7 \pm 0.1$ & 0 \\
\hline 33 & Thinned & 525 & 305 & 18 & 974 & 3.01 & $5.3 \pm 0.1$ & 260 \\
\hline 34 & Thinned & 466 & 150 & 16 & 455 & 4.18 & $7.6 \pm 0.1$ & 0 \\
\hline 35 & Thinned & 473 & 160 & 14 & 390 & 5.52 & $7.7 \pm 0.1$ & 260 \\
\hline 36 & Thinned & 482 & 350 & 25 & 715 & 2.01 & $5.2 \pm 0.2$ & 2339 \\
\hline 37 & Thinned & 459 & 15 & 20 & 844 & 2.59 & $4.2 \pm 0.1$ & 260 \\
\hline
\end{tabular}

Table A2. Structural characteristics of the main resprouter (strict or facultative) species: Mean ( \pm S.E.) values of maximum resprout height $(\mathrm{cm})$, crown cover $\left(\mathrm{cm}^{2}\right)$ and biovolume $\left(\mathrm{dm}^{3}\right)$ measured 6 months after the fire event.

\begin{tabular}{ccccc}
\hline Species & $\boldsymbol{n}$ & Total Height $\mathbf{( c m )}$ & Cover $\left.\mathbf{( c m}^{\mathbf{2}}\right)$ & Biovolume $\mathbf{( d m}^{\mathbf{3}} \mathbf{)}$ \\
\hline A. ovalis & 11 & $37 \pm 1.0$ & $4149 \pm 239$ & $301 \pm 18.40$ \\
A. unedo & 30 & $46 \pm 0.8$ & $352 \pm 111$ & $231 \pm 8.04$ \\
C. emerus & 14 & $5 \pm 0.1$ & $73 \pm 5$ & $0.5 \pm 0.04$ \\
D. pentaphyllum & 20 & $11 \pm 0.2$ & $251 \pm 6$ & $3.48 \pm 0.13$ \\
E. multifolora & 234 & $7 \pm 0.1$ & $76 \pm 3$ & $0.69 \pm 0.03$ \\
G. alypum & 29 & $7 \pm 0.1$ & $64 \pm 2$ & $0.59 \pm 0.03$ \\
G. scorpius & 164 & $12 \pm 0.2$ & $139 \pm 5$ & $2.28 \pm 0.16$ \\
J. oxycedrus & 22 & $11 \pm 0.1$ & $153 \pm 5$ & $2.03 \pm 0.08$ \\
L. implexa & 61 & $28 \pm 0.8$ & $445 \pm 21$ & $22.94 \pm 2.25$ \\
O. europaea & 13 & $26 \pm 0.4$ & $503 \pm 15$ & $16.50 \pm 0.57$ \\
P. angustifolia & 12 & $28 \pm 0.6$ & $640 \pm 32$ & $33.80 \pm 2.61$ \\
P. latifolia & 21 & $51 \pm 0.9$ & $4718 \pm 222$ & $396.36 \pm 23.07$ \\
\hline
\end{tabular}


Table A2. Cont.

\begin{tabular}{ccccc}
\hline Species & $\boldsymbol{n}$ & Total Height $\mathbf{( c m )}$ & Cover $\left(\mathbf{c m}^{\mathbf{2}}\right)$ & Biovolume $\left(\mathbf{d m}^{\mathbf{3}}\right)$ \\
\hline P. lentiscus & 75 & $22 \pm 0.4$ & $392 \pm 18$ & $14.28 \pm 0.95$ \\
Q. cerrioides & 29 & $34 \pm 0.4$ & $2118 \pm 67$ & $90.13 \pm 3.47$ \\
Q. coccifera & 87 & $29 \pm 0.7$ & $482 \pm 21$ & $23.29 \pm 1.46$ \\
R. ulmifolius & 56 & $22 \pm 0.4$ & $596 \pm 30$ & $22.70 \pm 1.59$ \\
T. tinctoria & 18 & $17 \pm 0.4$ & $1370 \pm 82$ & $42.12 \pm 3.14$ \\
V. lantana & 28 & $8 \pm 0.1$ & $89 \pm 3$ & $1.07 \pm 0.05$ \\
V. tinus & 61 & $10 \pm 0.2$ & $65 \pm 3$ & $0.92 \pm 0.06$ \\
\hline
\end{tabular}

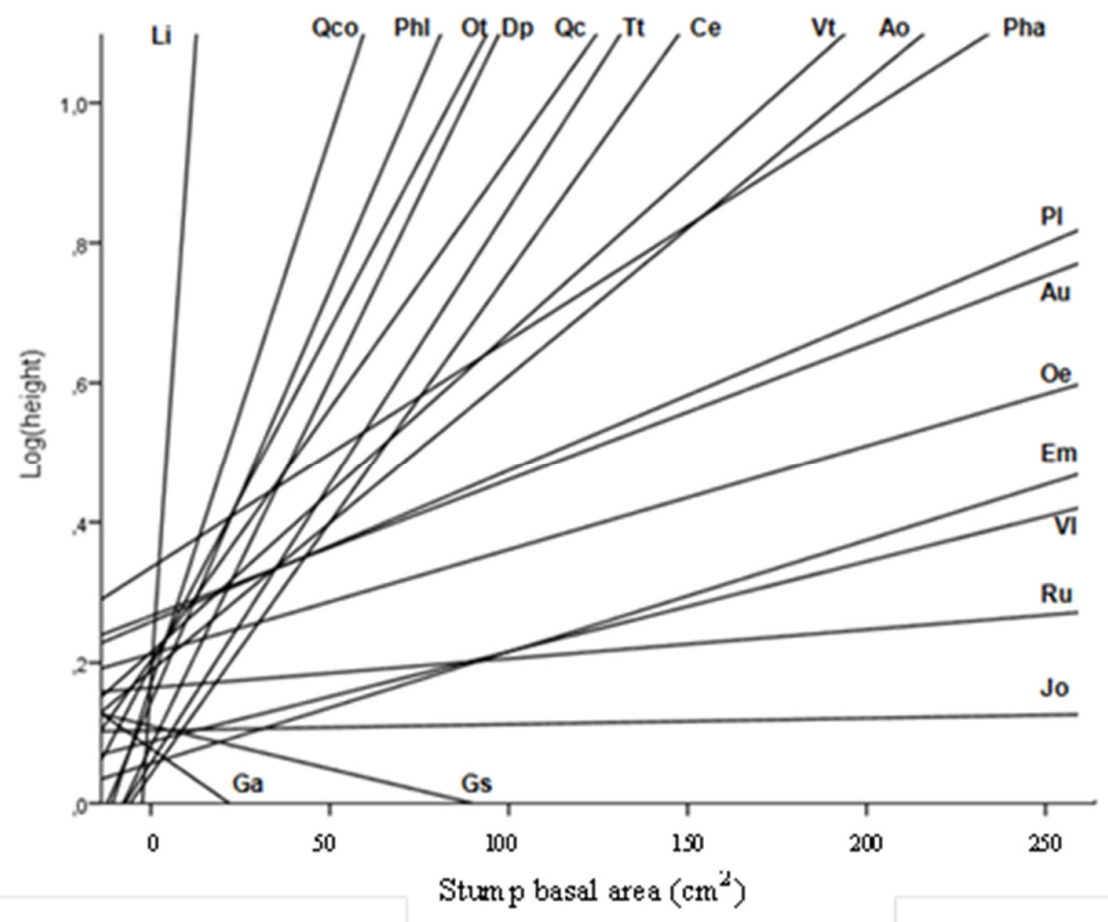

Figure A1. Relationship between individual stump basal area and individual maximum height (log-transformed) for the 20 resprouter species. Relationship between individual stump basal area with resprouting cover and biovolume (both log-transformed) are not shown because they provided similar results. See Table A2 for species nomenclature.

\section{References}

1. Pausas, J.G. Changes in fire and climate in the eastern Iberian Peninsula (Mediterranean Basin). Clim. Chang. 2004, 63, 337-350. [CrossRef]

2. Buhk, C.; Meyn, A.; Jentsch, A. The challenge of plant regeneration after fire in the Mediterranean Basin: scientific gaps in our knowledge on plant strategies and evolution of traits. Plant Ecol. 2007, 192, 1-19. [CrossRef]

3. De Las Heras, J.; Moya, D.; Vega, J.A.; Daskalakou, E.; Vallejo, R.; Grigoriadis, N.; Tsitsoni, T.; Baeza, J.; Valdecantos, A.; Fernández, C.; et al. Post-Fire management of serotinous pine forests. In Post-Fire Management and Restoration of Southern European Forests; Moreira, F., Arianoutsou, M., Corona, P., de las Heras, J., Eds.; Springer: Dordrecht, The Netherlands, 2012; Volume 24, pp. 121-150.

4. Hanes, T.L. Succession after fire in the chaparral of southern California. Ecol. Monogr. 1971, 41, $27-52$. [CrossRef]

5. Rodrigo, A.; Retana, J.; Picó, F.X. Direct regeneration is not the only response of Mediterranean forests to large fires. Ecology 2004, 85, 716-729. [CrossRef] 
6. Calvo, A.; Cerdà, A. An example of the changes in the hydrological and erosional response of soil after a forest fire, Pedralba (Valencia), Spain. In Soil Erosion as a Consequence of Forest Fires; Sala, M., Rubio, J.L., Eds.; Geoforma Ediciones: Logroño, Spain, 1994; pp. 99-110.

7. De las Heras, J.; Moya, D.; Lopez-Serrano, F.R.; Rubio, E. Carbon sequestration of naturally regenerated Aleppo pine stands in response to early thinning. New For. 2013, 44, 457-470. [CrossRef]

8. Alfaro-Sanchez, R.; Lopez-Serrano, F.R.; Rubio, E.; Moya, D.; Sanchez-Salguero, R.; de las Heras, J. Biomass storage in low timber productivity Mediterranean forests managed after natural post-fire regeneration in south-eastern Spain. Eur. J. For. Res. 2014, 133, 793-807. [CrossRef]

9. Verkaik, I.; Espelta, J.M. Post-Fire regeneration thinning, cone production, serotiny and regeneration age in Pinus halepensis. For. Ecol. Manag. 2006, 231, 155-163. [CrossRef]

10. Moya, D.; Espelta, J.M.; Verkaik, I.; López-Serrano, F.; de Las Heras, J. Tree density and site quality influence on Pinus halepensis Mill. reproductive characteristics after large fires. Ann. For. Sci. 2007, 64, 649-656. [CrossRef]

11. Zedler, P.H. Fire frequency in southern California shrublands: Biological effects and management options. In Bushfires in California Wildlands: Ecology and Resource Management; Keeley, J.E., Scott, T., Eds.; International Association of Wildland Fire: Fairfield, CA, USA, 1995; pp. 101-112.

12. Ne'eman, G.; Goubitz, S.; Nathan, R. Reproductive traits of Pinus halepensis in the light of fire-A critical review. Plant Ecol. 2004, 171, 69-79. [CrossRef]

13. Alfaro-Sanchez, R.; Lopez-Serrano, F.R.; Rubio, E.; Sanchez-Salguero, R.; Moya, D.; Hernandez-Tecles, E.; de las Heras, J. Response of biomass allocation patterns to thinning in Pinus halepensis differs under dry and semiarid Mediterranean climates. Ann. For. Sci. 2015, 72, 595-607. [CrossRef]

14. Alfaro-Sanchez, R.; Camarero, J.J.; Lopez-Serrano, F.R.; Sanchez-Salguero, R.; Moya, D.; de las Heras, J. Positive coupling between growth and reproduction in young post-fire Aleppo pines depends on climate and site conditions. Int. J. Wildland Fire 2015, 24, 507-517. [CrossRef]

15. Francos, M.; Ubeda, X.; Tort, J.; Panareda, J.M.; Cerdà, A. The role of forest fire severity on vegetation recovery after 18 years. Implications for forest management of Quercus suber L. in Iberian Peninsula. Glob. Planet. Chang. 2016, 145, 11-16. [CrossRef]

16. González-Ochoa, A.I.; López-Serrano, F.R.; de Las Heras, J. Does post-fire forest management increase tree growth and cone production in Pinus halepensis? For. Ecol. Manag. 2004, 188, 235-247. [CrossRef]

17. Moya, D.; de las Heras, J.; López-Serrano, F.R.; Leone, V. Optimal intensity and age of management in young aleppo pine stands for post-fire resilience. For. Ecol. Manag. 2008, 255, 3270-3280. [CrossRef]

18. Alfaro-Sanchez, R.; Sanchez-Salguero, R.; de las Heras, J.; Hernández-Tecles, E.; Moya, D.; Lopez-Serrano, F.R. Vegetation dynamics of managed Mediterranean forests 16 year after large fires in southeastern Spain. Appl. Veg. Sci. 2015, 18, 272-282. [CrossRef]

19. Palmero-Iniesta, M. Fire Behavior in Pinus Halepensis Thickets: Effects of Thinning and Woody Debris Decomposition in Different Climatic Scenarios. Master's Thesis, Master en Incendios Forestales: Ciencia y gestión integral, Universitat de Lleida, Lleida, Spain, September 2016.

20. Domènech-Jardí, R.; Pastor-Ferrer, E.; Agueda-Costafreda, A.; Sans, A.; Navascués, P.; Planas-Cuchi, E. Modelos de combustible para caracterizar el comportamiento de los incendios en regenerados clareados de pino carrasco. Montes 2013, 115, 22-29.

21. Fulé, P.Z.; Waltz, A.E.M.; Covington, W.W.; Heinlein, T.A. Measuring forest restoration effectiveness in reducing hazardous fuels. J. For. 2001, 99, 24-29.

22. Agee, J.K.; Skinner, C.N. Basic principles of forest fuel reduction treatments. For. Ecol. Manag. 2005, 211, 83-96. [CrossRef]

23. Brown, R.T.; Agee, J.K.; Franklin, J.F. Forest restoration and fire: Principles in the context of place. Conserv. Biol. 2004, 18, 903-912. [CrossRef]

24. Pausas, J.G.; Ribeiro, E.; Vallejo, R.V. Post-Fire regeneration variability of Pinus halepensis in the eastern Iberian Peninsula. For. Ecol. Manag. 2004, 203, 251-259. [CrossRef]

25. Eugenio, M.; Verkaik, I.; Lloret, F.; Espelta, J.M. Recruitment and growth decline in Pinus halepensis populations after recurrent wildfires in Catalonia (NE Iberian Peninsula). For. Ecol. Manag. 2006, 231, 47-54. 
26. Turner, M.G.; Romme, W.H.; Gardner, R.H. Prefire heterogeneity, fire severity, and early postfire plant reestablishment in subalpine forests of Yellowstone National Park, Wyoming. Int. J. Wildland Fire 1999, 9, 21-36. [CrossRef]

27. Pausas, J.G.; Ouadah, N.; Ferran, A.; Gimeno, T.; Vallejo, R.V. Fire severity and seedling establishment in Pinus halepensis woodlands, eastern Iberian Peninsula. Plant Ecol. 2003, 169, 205-213. [CrossRef]

28. Schwartz, N.B.; Urban, D.L.; White, P.S.; Moody, A.; Klein, R.N. Vegetation dynamics vary across topographic and fire severity gradients following prescribed burning in Great Smoky Mountains National Park. For. Ecol. Manag. 2016, 365, 1-11. [CrossRef]

29. Ninyerola, M.; Pons, X.; Roure, J.M. A methodological approach of climatological modelling of air temperature and precipitation through GIS techniques. Int. J. Climatol. 2000, 20, 1823-1841. [CrossRef]

30. Panareda-Clopés, J.M.; Nuet-Badia, J. Tipología y cartografía corológica de las plantas vasculares de Montserrat (Cordillera Prelitoral Catalana). Rev. Geogr. 1993, 27, 33-58.

31. Panetsos, K.P. Monograph of Pinus halepensis Mill. and P. brutia Ten. Ann. For. Zagreb. 1981, 9, 39-77.

32. Llobet, S. Propuesta de modelo silvícola para montes de pino carrasco (Pinus halepensis). In Modelos Silvícolas en Bosques Privados Mediterraneos; Colección Documentos de Trabajo, Serie_Territorio 5; Diputació de Barcelona: Barcelona, Spain, 2008; pp. 109-145.

33. Omi, P.N.; Kalabokidis, K.D. Fire damage on extensively vs. intensively managed forest stands within the North Fork Fire, 1988. Northwest Sci. 1991, 65, 149-157.

34. Weatherspoon, C.P.; Skinner, C.N. An assessment of factors associated with damage to tree crowns from the 1987 wildfires in northern California. For. Sci. 1995, 41, 430-451.

35. Habrouk, A.; Retana, J.; Espelta, J.M. Role of heat tolerance and cone protection of seeds in the response of three pine species to wildfires. Plant Ecol. 1999, 145, 91-99. [CrossRef]

36. Espelta, J.M.; Retana, J.; Habrouk, A. Resprouting patterns after fire and response to stool cleaning of two coexisting Mediterranean oaks with contrasting leaf habits on two different sites. For. Ecol. Manag. 2003, 179, 401-414. [CrossRef]

37. Espelta, J.M.; Barbati, A.; Quevedo, L.; Tárrega, R.; Navascués, P.; Bonfil, C.; Peguero, G.; Fernández-Martínez, M.; Rodrigo, A. Post-Fire management of Mediterranean broadleaved forests. In Post-Fire Management and Restoration of Southern European Forests; Moreira, F., Arianoutsou, M., Corona, P., de las Heras, J., Eds.; Springer: Dordrecht, The Netherlands, 2012; Volume 24, pp. 171-194.

38. Quevedo, L.; Rodrigo, A.; Espelta, J.M. Post-Fire resprouting ability of 15 non-dominant shrub and tree species in Mediterranean areas of NE Spain. Ann. For. Sci. 2007, 64, 883-890. [CrossRef]

39. R Development Core Team. R: A Language and Environment for Statistical Computing; R Foundation for Statistical Computing: Vienna, Austria, 2015.

40. Bates, D.; Mächler, M.; Bolker, B.; Walker, S. Fitting linear mixed-effects models using lme4. J. Stat. Softw. 2015, 67, 1-48. [CrossRef]

41. Barton, K. MuMIn: Multi-Model Inference. R Package Version 1.15.1. 2015. Available online: http:/ /CRAN. R-project.org/package=MuMIn (accessed on 23 March 2016).

42. Pollet, J.; Omi, P.N. Effect of thinning and prescribed burning on crown fire severity in ponderosa pine forests. Int. J. Wildland Fire 2002, 11, 1-10. [CrossRef]

43. Carey, H.; Schumann, M. Modifying wildfire behavior-The effectiveness of fuel treatments: The status of our knowledge. 2003, in press.

44. Anderson, H.E. Aids to Determining Fuel Models for Estimating Fire Behavior; USDA Forest Service, Intermountain Forest and Range Experiment Station: Ogden, UT, USA, 1982.

45. Kalabokidis, K.D.; Omi, P.N. Reduction of fire hazard through thinning/residue disposal in the urban interface. Int. J. Wildland Fire. 1998, 8, 29-35. [CrossRef]

46. Ordóñez, J.L.; Retana, J.; Espelta, J.M. Effects of tree size, crown damage, and tree location on post-fire survival and cone production of Pinus nigra trees. For. Ecol. Manag. 2005, 206, 109-117. [CrossRef]

47. Herranz, J.; Martínez-Sánchez, J.J.; Martín, A.; Ferrandis, P. Postfire regeneration of Pinus halepensis Miller in a semi-arid area in Albacete province (southeastern Spain). Écoscience 1997, 4, 86-90. [CrossRef]

48. Tsitsoni, T. Conditions determining natural regeneration after wildfires in the Pinus halepensis (Miller, 1768) forests of Kassandra Peninsula (North Greece). For. Ecol. Manag. 1997, 92, 199-208. [CrossRef] 
49. Castro, J.; Allen, C.D.; Molina-Morales, M.; Marañon-Jimenez, S.; Sanchez-Miranda, A.; Zamora, R. Salvage Logging Versus the Use of Burnt Wood as a Nurse Object to Promote Post-Fire Tree Seedling Establishment. For. Ecol. Manag. 2011, 19, 537-544. [CrossRef]

50. Fernandez, C.; Vega, J.A.; Fonturbel, T.; Jimenez, E.; Perez-Gorostiaga, P. Effects of wildfire, salvage logging and slash manipulation on Pinus pinaster Ait. recruitment in Orense (NW Spain). For. Ecol. Manag. 2008, 255, 1294-1304. [CrossRef]

51. Bonfil, P.; Cortes, P.; Espelta, J.M.; Retana, J. The role of disturbance in the co-existence of the evergreen Quercus ilex and the deciduous Quercus cerrioides. J. Veg. Sci. 2004, 15, 423-430. [CrossRef]

52. Klimešová, J.; Klimeš, L. Bud banks and their role in vegetative regeneration-A literature review and proposal for simple classification and assessment. Perspect. Plant Ecol. Evol. Syst. 2007, 8, 115-129. [CrossRef]

53. Peguero, G.; Espelta, J.M. Disturbance intensity and seasonality affect the resprouting ability of the neotropical dry-forest tree Acacia pennatula: Do resources stored below-ground matter? J. Trop. Ecol. 2011, 27, 539-546. [CrossRef]

54. Manes, F.; Capogna, F.; Puppi, G.; Vitele, M. Ecophysiological characterisation of Phillyrea angustifolia L. and response of resprouts to different fire disturbance intensities. In Fire and Biological Processes; Trabaud, L., Prodon, R., Eds.; Backhuys publishers: Leiden, The Netherlands, 2002; pp. 115-130.

55. Capogna, F.; Persiani, A.M.; Maggi, O.; Dowgiallo, G.; Puppi, G.; Manes, F. Effects of different fire intensities on chemical and biological soil components and related feedbacks on a Mediterranean shrub (Phillyrea angustifolia L.). Plant Ecol. 2009, 204, 155-171. [CrossRef]

56. Vilà, M.; Terradas, J. Effects of nutrient availability and neighbours on shoot growth, resprouting and flowering of Erica multiflora. J. Veg. Sci. 1995, 6, 411-416. [CrossRef]

57. Cotillas, M.; Espelta, J.M.; Sánchez-Costa, E.; Sabaté, S. Aboveground and belowground biomass allocation patterns in two Mediterranean oaks with contrasting leaf habit: An insight into carbon stock in young oak coppices. Eur. J. For. Res. 2016, 135, 243-252. [CrossRef]

58. Espelta, J.M.; Verkaik, I.; Eugenio, M.; Lloret, F. Recurrent wildfires constrain long-term reproduction ability in Pinus halepensis Mill. Int. J. Wildland Fire 2008, 17, 579-585. [CrossRef]

59. Espelta, J.M.; Arnan, X.; Rodrigo, A. Non-Fire induced seed release in a weakly serotinous pine: Climatic factors, maintenance costs or both? Oikos 2011, 11, 1752-1760. [CrossRef]

60. Graham, R.T.; Harvey, A.E.; Jain, T.B.; Tonn, J.R. The Effects of Thinning and Similar Stand Treatments on Fire Behavior in Western Forests; General Technical Report PNW-GTR-463; USDA Forest Service, Pacific Northwest Research Station: Seattle, WA, USA, 1999.

(C) 2017 by the authors. Licensee MDPI, Basel, Switzerland. This article is an open access article distributed under the terms and conditions of the Creative Commons Attribution (CC BY) license (http:/ / creativecommons.org/licenses/by/4.0/). 